\title{
THE INFLUENCE OF HOT-ROLLING REDUCTIONS AND PASSES ON THE MICROSTRUCTURE AND MECHANICAL PROPERTIES OF Mn18Cr18N ESR STEEL
}

\author{
VPLIV STOPENJ REDUKCIJE IN ŠTEVILA PREHODOV MED \\ VROČIM VALJANJEM NA MIKROSTRUKTURO IN MEHANSKE \\ LASTNOSTI JEKLA Mn18Cr18N ESR
}

\author{
Juan Li', Fengming Qin', Guanghui Zhao'.2, Huiqin Chen ${ }^{1 *}$ \\ 1Taiyuan University of Science and Technology, no. 66 Liuliu Road, Wanbailin District, Taiyuan 030024, Shanxi, China \\ ${ }^{2}$ Shanxi Provincial Key Laboratory of Metallurgical Device Design Theory and Technology, no. 66 Liuliu Road, Wanbailin District, \\ Taiyuan 030024, Shanxi, China \\ chen_huiqin@126.com
}

Prejem rokopisa - received: 2018-08-28; sprejem za objavo - accepted for publication: 2018-10-30

doi:10.17222/mit.2018.188

\begin{abstract}
The single-pass hot-rolling process with height reductions of $15 \%, 30 \%, 40 \%$ and $50 \%$, and the three-pass and the five-pass hot-rolling processes with $60 \%$ total reduction, were carried out for Mn18Cr18N ESR steel slabs. The influence of the hot-rolling reductions and passes on the microstructure and mechanical properties of the rolled samples was investigated. For the single-pass rolled process, the volume fraction of the refined dynamically recrystallized grains increased with the increasing of the reduction, both the tensile strength and elongation also increased with the increasing of the reduction, and the fracture morphology transformed to ductile at higher reductions. For the three-pass and the five-pass rolling processes, strain-hardening structures containing a large number of slip/shear bands and fewer refined dynamically recrystallized grains were present. The tensile strength increased with the increasing number of passes, but the elongation decreased with the increasing number of passes. The fracture morphologies were also characterised by brittle fractures. After the solid-solution treatment, uniform refined static recrystallized grains were obtained in the three-pass rolled part, while grain growth following static recrystallization occurred in the five-pass rolled part.

Keywords: Mn18Cr18N, rolling, microstructure, mechanical property
\end{abstract}

Avtorji članka so izvajali preizkuse vročega valjanja slabov iz jekla pretaljenega pod žlindro Mn18Cr18N ESR (angl.: Electro Slag Remelting) pri enem prehodu in z različnimi stopnjami redukcije (15\%,30\%, $40 \%$ in $50 \%)$, kakor tudi preizkuse s tremi in petimi prehodi pri celotni $60 \%$ redukciji. Pri tem so ugotavljali vpliv stopenj redukcije in števila prehodov na mikrostrukturo in mehanske lastnosti vroče valjanih vzorcev jekla. Pri vročem valjanju z enim prehodom so ugotovili, da se $\mathrm{z}$ naraščajočo stopnjo redukcije (deformacije) povečuje volumski delež udrobljenih dinamično rekristaliziranih kristalnih zrn. Posledično sta se tako povečali natezna trdnost in raztezek jekla, prav tako pa je morfologija preloma prešla v duktilno. Pri vročem valjanju s tremi in petimi prehodi je deformacijsko utrjena struktura vsebovala veliko število drsno/strižnih pasov in manjše število udrobljenih dinamično rekristaliziranih zrn. Natezna trdnost jekel se je poviševala s povečevanjem števila prehodov, medtem ko se je raztezek manjšal. Nastala je tipično krhka morfologija preloma. Po raztopnem žarenju so pri postopku valjanja s tremi prehodi ustvarili enovito rafinirano mikrostrukturo s statično rekristaliziranimi kristalnimi zrni, medtem ko je pri postopku valjanja s petimi prehodi rasti zrn sledila statična rekristalizacija.

Ključne besede: jeklo Mn18Cr18N, valjanje, mikrostruktura, mehanske lastnosti

\section{INTRODUCTION}

Mn18Cr18N, a high-nitrogen austenitic stainless steel, is widely used to manufacture the retaining rings of generators due to its distinctive advantages such as high strength and toughness, non-magnetic property and excellent stress corrosion resistance. ${ }^{1-2}$ Nitrogen, as an important alternative alloying element instead of nickel, can contribute to improve the stability of the austenitic structure, the mechanical properties and the corrosion resistance. ${ }^{3-4}$ The conventional manufacturing route of heavy retaining rings involves smelting, ingot consolidation, forging, heat treatment and machining. 5 The forging process includes ingot breakdown, upsetting, punching, mandrel drawing and mandrel expanding operations, which are complex and hard to control. The compact route for manufacturing retaining rings has been put forward; it involves only smelting and consolidation, electro-slag re-melting (ESR) a hollow ingot and ring rolling operations. ${ }^{6}$ Compared to the conventional manufacturing route, the compact route is simple, energysaving, material-saving and convenient to control. This compact route can be used to manufacture all kinds of rings and hollow parts, especially for large rings and hollow components. ESR ingots are generally compact, homogenized and pure. However, coarse grains, especially coarse columnar grains, are more prominent in ESR ingots. ${ }^{7-8}$ Therefore, the coarse columnar grain refinement during ring-rolling processes of lager hollow 
Table 1: Chemical composition of the Mn18Cr18N steel (w/\%)

\begin{tabular}{|c|c|c|c|c|c|c|c|c|c|c|c|c|}
\hline $\mathrm{C}$ & $\mathrm{Mn}$ & $\mathrm{Si}$ & $\mathrm{P}$ & $\mathrm{S}$ & $\mathrm{Ni}$ & $\mathrm{Cr}$ & $\mathrm{Mo}$ & $\mathrm{V}$ & $\mathrm{Al}$ & $\mathrm{N}$ & $\mathrm{Ti}$ & $\mathrm{Fe}$ \\
\hline 0.074 & 19.21 & 0.59 & 0.014 & 0.001 & 0.14 & 20 & 0.022 & 0.053 & 0.023 & 0.6 & 0.016 & Balance \\
\hline
\end{tabular}

ingots has become a challenge for manufacturing highquality retaining rings, and the investigation of coarse columnar grain refinement during the ring-rolling processes of the steel plays an important role with regards to optimizing the ring-rolling process parameters.

For austenitic stainless steels with a lower stacking fault energy (SFE), grain refinement can be realized by dynamic recrystallization (DRX) during hot deformation and/or static recrystallization (SRX) during the inter-pass of hot deformation. Qin found that DRX controlled by dislocation and twining mechanisms occurs during the hot deformation of ESR Mn18Cr18N ingots, which depends mainly on the strain rates. ${ }^{9}$ DRX controlled by dislocation slipping and a climbing mechanism occurs at lower strain rates, in which the equiaxed recrystallized grains are composed of recovered sub-grains with lowangle boundaries and various dislocation configurations; DRX controlled by a twinning mechanism occurs at higher strain rates, in which most of the recrystallized grains are composed of twins, micro-twins and dislocation cells in twins. However, grain refinement by DRX usually needs large deformations. Therefore, the hot workability is a major concern for the hot deformation of ESR ingots. Based on hot-processing maps, the hotworking windows of an ESR as-cast Mn18Cr18N ingot steel should be in the temperature and strain-rate ranges of $1050-1200{ }^{\circ} \mathrm{C}, 0.001-0.01 \mathrm{~s}^{-1}$ and $1100-1200{ }^{\circ} \mathrm{C}$, $0.1-1 \mathrm{~s}^{-1}$, in which the DRX controlled by the dislocation slip mechanism and the twinning mechanism occur, respectively. ${ }^{10}$ The alternative method for the grain refinement of austenitic stainless steels is SRX during the inter-pass of deformation or heat treatments after hot deformation, in which the deformation and duration

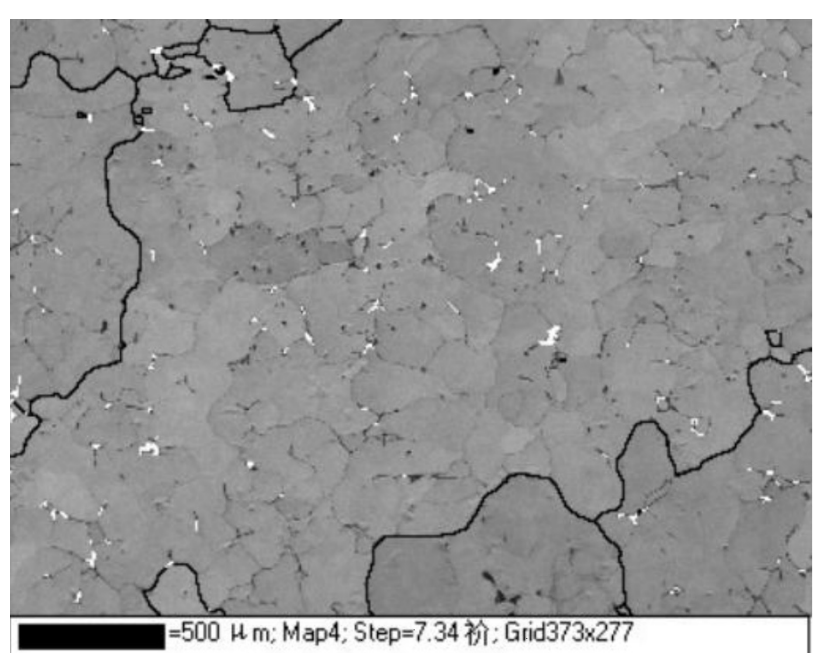

Figure 1: Microstructure of Mn18Cr18N ESR during the inter-pass of the hot deformation or the parameters of the heat-treatment process have to be matched.

In the present work, different hot-rolling reductions and passes have been designed to investigate the microstructure evolution and the mechanical properties of Mn18Cr18N ESR steel, which can provide a scientific basis for designing and optimizing the ring-rolling process in the compact route for manufacturing large retaining rings.

\section{MATERIALS AND EXPERIMENTAL PART}

The material in this investigation was $\mathrm{Mn} 18 \mathrm{Cr} 18 \mathrm{~N}$ austenitic stainless steel with $0.61 \%(w / \%)$ nitrogen received as an ESR ingot with a diameter of $300 \mathrm{~mm}$ and a height of $130 \mathrm{~mm}$. The chemical composition of the steel is shown in Table 1. The original microstructure of the ESR ingot is shown in Figure 1. The ingot steel was composed of coarse columnar grains with sizes of $500-1000 \mu \mathrm{m}$ at about $60^{\circ}$ to the axis of the ingot, in which uniform and fine sub-grains with a size of $50 \mu \mathrm{m}$ can be observed.

The rectangular rolling slabs were $100 \mathrm{~mm}$ in length, $90 \mathrm{~mm}$ in width and $12 \mathrm{~mm}$ in thickness, machined from the ESR ingot. The length direction is parallel to the axis of the ESR ingot. The rolling tests were conducted on a rolling mill with rollers of $320 \mathrm{~mm}$ in diameter. The slabs were heated to $1200{ }^{\circ} \mathrm{C}$ and held for $15 \mathrm{~min}$ for the rolling. The single-pass rolling processes with $15 \%$, $30 \%, 40 \%$ and $50 \%$ reductions were designed for investigating the influence of single reductions on the microstructure evolution and the mechanical properties of the rolling parts. The three-pass and five-pass rolling processes with $60 \%$ total reductions and an $8 \mathrm{~s}$ inter-pass duration were designed for investigating the influence of passes on the microstructure evolution and the mechanical properties of the rolling parts. For the three-pass rolling process, the rolling path was $20 \%$ $40 \%-20 \%$. For the five-pass rolling process, the rolling path was $10 \%-20 \%-30 \%-20 \%-10 \%$. For all the rolling processes, the rolling velocity was $0.2 \mathrm{~m} / \mathrm{s}$.

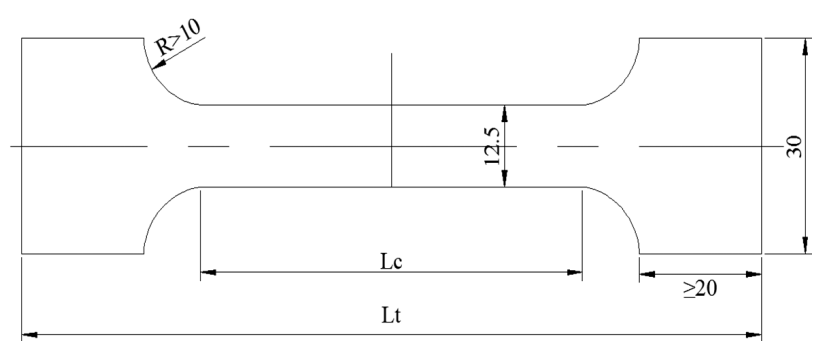

Figure 2: Schematic of the tensile-test specimen after rolling 
The rolled parts were quenched by water after rolling. The RD-ND sectional samples were taken longitudinally to the rolling direction and prepared for microscopic and fractographic observations by SEM and EBSD on a ZEISS SIGMA. In the EBSD grain-boundary reconstruction maps, low-angle grain boundaries $\left(2-15^{\circ}\right.$, LAGB) were expressed by white lines; and the high-angle grain boundaries $\left(\geq 15^{\circ}\right.$, HAGB) were expressed by black lines. The mechanical property test samples were machined according to GB/T 6396-2008 and tested on a WDW-200 tensile testing machine. As the sample thickness after rolling is different, the dimensions of the tensile samples are shown in Figure 2 and Table 2.

Table 2: Dimensions of the tensile samples

\begin{tabular}{|c|c|c|c|}
\hline Rolling pass & Reduction $/ \%$ & $\mathrm{Lc} / \mathrm{mm}$ & $\mathrm{Lt} / \mathrm{mm}$ \\
\hline \multirow{3}{*}{1} & 15 & 84 & 144 \\
\cline { 2 - 4 } & 30 & 76 & 136 \\
\cline { 2 - 4 } & 40 & 71 & 131 \\
\cline { 2 - 4 } & 50 & 65 & 124 \\
\hline $3 / 5$ & 60 & 63 & 123 \\
\hline
\end{tabular}

\section{RESULTS}

\subsection{Microstructure evolution during different rolling passes}

Figure 3 shows the microstructures for the singlepass rolled samples with $15 \%, 30 \%, 40 \%$ and $50 \%$ reductions. It is clear that the refined grains and twins increase with the increasing of the reductions. In Figure 3a there were no refined grains observed due to the lower reduction of $15 \%$. However, the original as-cast coarse grains elongated with the waved grain boundaries. Two groups of cross-slip lines were also observed, which is often observed in lager grains during deformation. ${ }^{11}$ In addition, waved grain boundaries have often been considered as an early stage of nucleation for the DRX grains. ${ }^{12}$ In the sample compressed up to $30 \%$ reduction (Figure 3b), some refined grains located at the grain boundaries formed, while the center part of the original
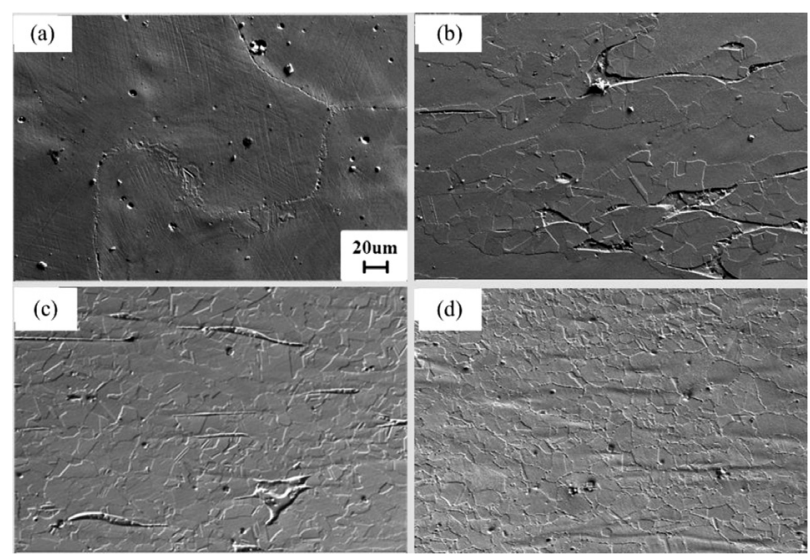

Figure 3: Microstructures of the single-pass rolled samples with different reductions: a) $15 \%$, b) $30 \%$, c) $40 \%$, d) $50 \%$ grains remains un-refined due to a smaller DRX fraction. When the reduction was up to $40 \%$ (Figure 3c), the DRX was almost completed. However, the DRX-refined grains were not uniform and $\delta$ ferrite remains as the original grain boundaries and morphology, which is not beneficial to the mechanical properties of the rolled parts. As shown in Figure 3d, when the reduction was up to $50 \%$, the near fully DRX refined grains were obtained and $\delta$ ferrite could hardly be observed. This suggests that the $40 \%$ reduction in the single-pass rolling process is enough for DRX; but the greater reduction over $40 \%$ is necessary for the uniformly refined DRX grain structure that is nearly free of $\delta$-ferrite. Because the rolling process was a non-isothermal and non-constant strain-rate process, the size of the refined DRX grains decreases with the increasing of the reduction. At a reduction of $50 \%$, the size of the refined DRX grains was about $50 \mu \mathrm{m}$, which almost equals the size of the sub-grains in the parent as-cast coarse grains. This implies that the refined DRX grains might be evolved from the sub-grains of the parent as-cast grains directly, which needs to be further confirmed.

For metals with a low or medium stacking-fault energy (SFE), DRX is considered to be the dominant microstructure-evolution mechanism during hot deformation. The SFE of Mn18Cr18N steel has been calculated to be about $24 \mathrm{~mJ} / \mathrm{m}^{2},{ }^{9}$ which also suggests that DRX might take place during the hot rolling of the steel. In DRX, nucleation generally prefers to occur at original grain boundaries (the yellow arrows in Figures $4 \mathbf{a}$ and 4b), slipping bands or shear bands (the white arrows in Figures $4 \mathbf{a}$ and $\mathbf{4 b}$ ). This is because the dislocations slip and pile up at the grain boundaries, which induces orientation evolution and preferential nucleation at the boundaries. ${ }^{13}$ However, the slipping band and the shear band can accelerate the dislocation movement and its evolution in preference to nucleation. As shown in Figure 4a, a few new recrystallized grains at the parent

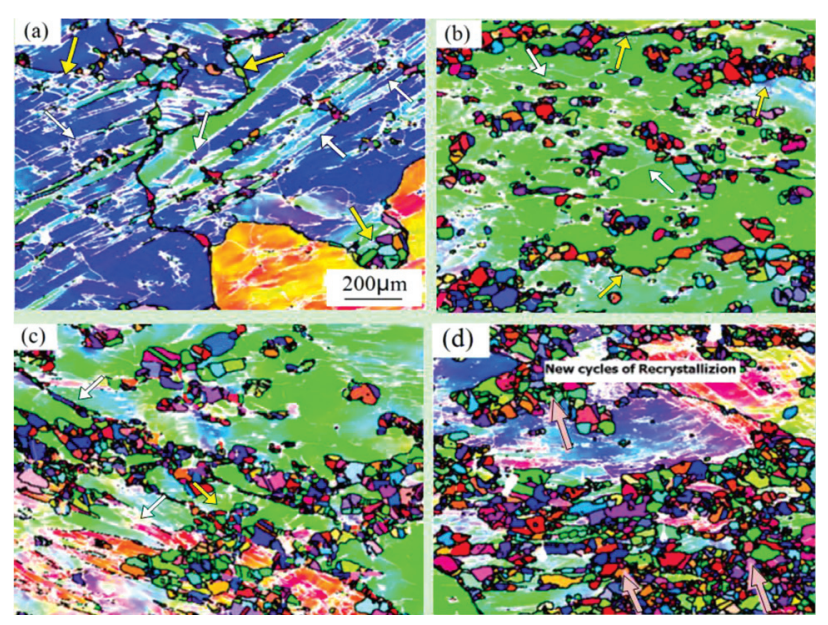

Figure 4: EBSD grain-boundary reconstruction maps of the singlepass rolled samples a) $15 \%$, b) $30 \%$, c) $40 \%$, d) $50 \%\left(2-15^{\circ}-\right.$ White, $>15^{\circ}$-Black) 
grain boundaries formed due to the lower reduction. Meanwhile, a large number of low-angle grain boundaries and slipping bands appeared in the interior of the parent grains, which are characteristics of the sub-structures in strain-hardening and DRV materials. With the increasing of the reduction, the first layer of the newly recrystallized grains formed at the elongated parent grain boundaries and slipping bands (Figure $4 \mathbf{b}$ ). The higher the reduction was, the more recrystallized grain layers there were (Figures $\mathbf{4 c}$ and $\mathbf{4 d}$ ). When the reduction was high enough, the DRX completed and a fully recrystallized grain structure was present. And new cycles of recrystallization formed at the grain boundaries and the three-grain junctions (the pink arrows in Figure 4d).

The binomial misorientation distributions in Figures 5 indicated that discontinuous DRX occurred during the single-pass rolling processes. Most of low-angle grain boundaries (LAGBs) were less than $10^{\circ}$, while most of the high-angle grain boundaries (HAGBs) were between $40^{\circ}-50^{\circ}$ or at $60^{\circ}$. With the increasing of the reduction, the average misorientation increased from $9.5^{\circ}$ to $45.5^{\circ}$. When the reduction was less than $30 \%$ (Figures 5a and 5b), the average misorientation was less than $10.5^{\circ}$, which suggests that the DRV dominates. As shown in Figures $\mathbf{5 c}$ and $\mathbf{5 d}$, the DRX dominates when the reduction was greater than $40 \%$. The misorientation of $60^{\circ}$ predominated in the HAGBs in Figures $\mathbf{5 b}$ to $\mathbf{5 d}$. It was reported that the $60^{\circ}$ misorientation is related to twin boundaries, ${ }^{14}$ which implies that twining plays an important role in DRX. This is in agreement with the research results in the literature. ${ }^{9}$

Figure 6 shows the microstructure and its characteristics for the three-pass rolled sample. It is clear that the original as-cast coarse grains elongated along the deformation direction, in which a large number of deformation bands were observed in Figure 6a. The EBSD grain-boundary reconstruction map of the three-pass rolled sample in Figure 6a also reveals that a certain amount of refined grains formed at the original coarse
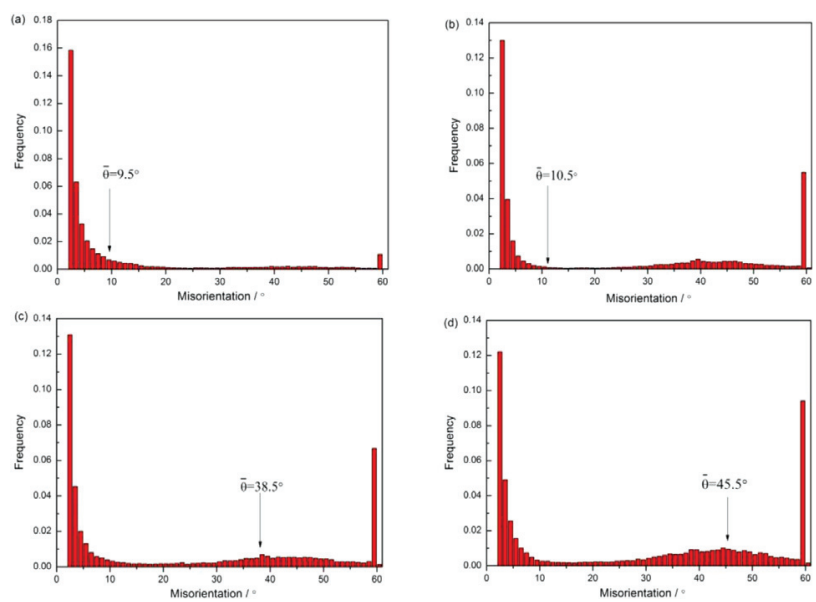

Figure 5: Misorientation distributions of the single-pass rolled samples a) $15 \%$, b) $30 \%$, c) $40 \%$,d) $50 \%$

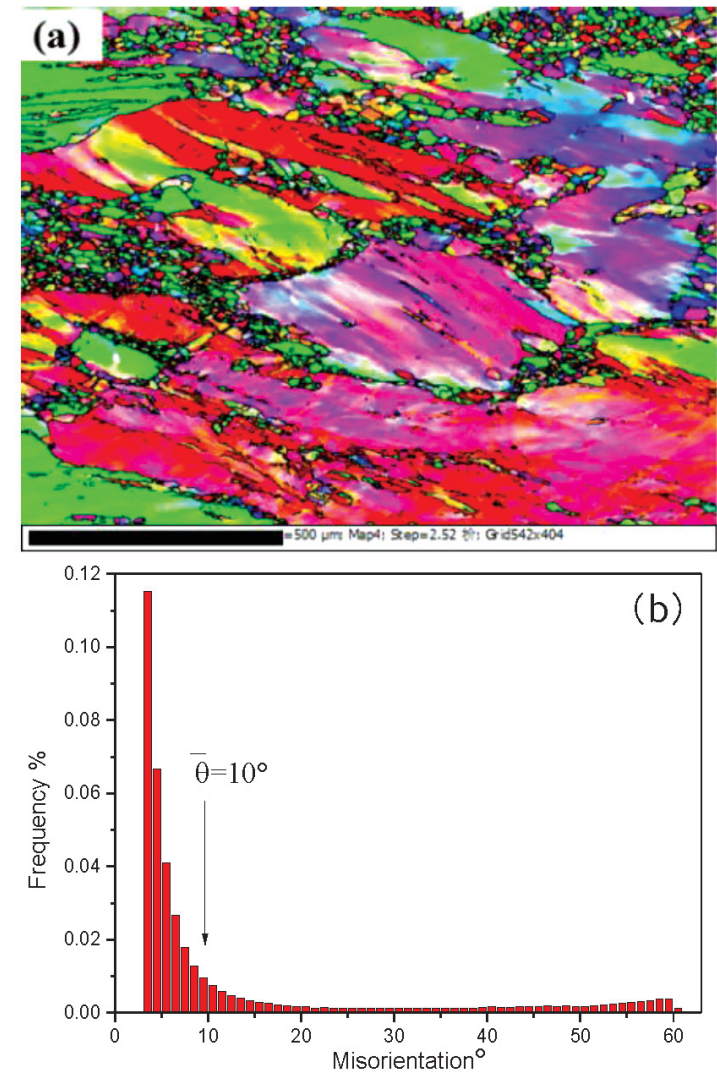

Figure 6: EBSD grain-boundary reconstruction map (a) and the corresponding misorientation distributions (b) after three rolling passes

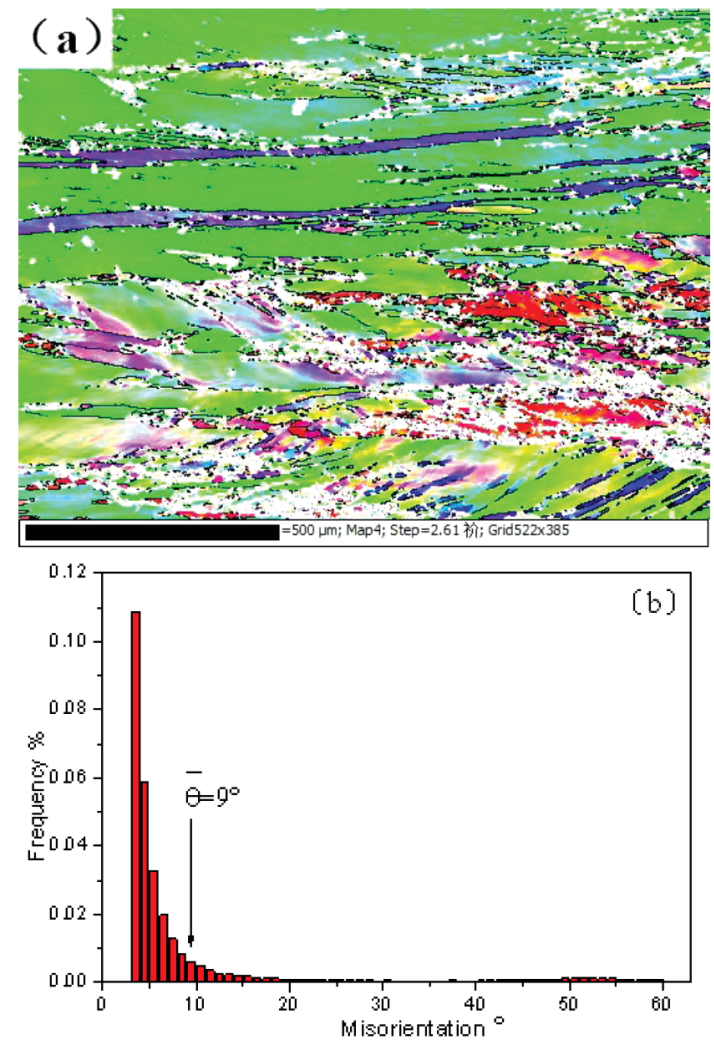

Figure 7: a) EBSD grain-boundary reconstruction map and b) the corresponding misorientation distributions after five rolling passes 
grain boundaries and the intra-granular deformation bands. However, Figure $\mathbf{6 b}$ shows that low-angle grain boundaries predominated in the microstructure, which suggests that the microstructure of the three-pass rolled sample was almost in the deformation-hardening state after the three-pass rolling process with the $20 \%-40 \%$ $-20 \%$ reduction sequence in the experiment.

Figure 7 shows the microstructure and its characteristics for the five-pass rolled sample. It can be seen that the original as-cast coarse grains elongated severely along the deformation direction in Figure 7a, compared to that of the sample after the three-pass rolling process in Figure 6a. The intra-granular deformation bands were even thinner, and a small amount of refined grains formed at the original coarse grain boundaries and the intra-granular deformation bands. Figure $\mathbf{7 b}$ also shows that low-angle grain boundaries also predominated in the microstructure, which suggests that the microstructure of the five-pass rolled sample was almost in the deformation hardening state after the five-pass rolling process with the $10 \%-20 \%-30 \%-20 \%-10 \%$ reduction sequence in the experiment.

\subsection{Mechanical properties of the rolled parts}

The mechanical properties of the hot-rolled parts were tested and shown in Table 3. It is clear that both of the strength indexes (the yield strength and the tensile strength) and the plasticity index (the elongation ratio) increased with the increasing reductions in the singlepass process. Although the strength indexes also increased with the increasing number of hot-rolling passes, the plasticity index decreased with the increasing number of hot-rolling passes.

During the single-pass rolling process, the greater is the reduction, the higher is the dislocation density, so that the higher is the strength. When the reduction increased up to the critical strain for the DRX of the steel at the experimental deformation parameters, the DRX occurred as shown in Figure 3. Therefore, new refined DRX grains formed. Although, refined DRX grains with a lower dislocation density compared to the strainhardened parent grains can decrease the strain hardening rate, the strength of the deformation material can be improved by the refined DRX grains based on the Hall-Patch relationship at room temperature, and the plasticity of the deformation material can also be improved by the refined DRX grains.

For DRX, the critical strain is needed to initiate the DRX. During the three-pass and five-pass rolling processes, the microstructures in the rolled parts were elongated, hardening the coarse grains with fewer DRX refined grains at the grain boundaries and slipping bands (as shown in Figures 6 and 7) due to the lower reduction of each pass and the shorter holding time between the inter-pass, and the DRX or static recrystallization (SRX) can hardly occur. Therefore, the strength indexes increased with the increasing number of rolling passes, but the the plasticity of the elongation ratio decreased with the increasing number of rolling passes.

The tensile test results also indicate that no obvious necking occurred in the tensile samples machined from the three-pass and five-pass rolled parts, which was similar to that of the tensile samples machined from the single-pass rolled part with a reduction of $15 \%$. The necking increased with the increasing reduction of the single-pass rolled parts. Figure 8 shows the fracture morphologies of the single-pass and multi-pass rolled parts. It can also be seen that the fracture transformed from brittle fracture to ductile fracture with the increasing reductions of the single-pass parts corresponding to the fracture morphologies from Figures 8a to 8d. And the fracture in Figure 8d with the maximum reduction of $50 \%$ after the single-pass rolling process was a typical ductile fracture. However, the fractures of Figures 8a, 8e and $\mathbf{8 f}$ were more likely brittle fractures.

\section{DISCUSSION}

During the hot-rolling process, the initial microstructure state and the deformation parameters of the temperature, strain rate, reduction, pass and inter-pass holding times, have a comprehensive influence on the microstructure and the mechanical properties of hotrolled parts. ${ }^{15-16}$ Therefore, it is a challenge to optimize the rolling process for improving the microstructure and the mechanical properties of the ESR as-cast billets.

For metals with a low SFE, shear bands could often be observed in the deformed grains, except for the dislocation slipping and twinning. ${ }^{17}$ During the hot-rolling process, the reduction in each pass plays an important role in refining the grains of the rolled parts. When the reduction is lower than the critical strain of DRX, as indicated in Figure 3a, the initial as-cast coarse grains will be elongated along the rolling direction with various dislocation configurations inside. Meanwhile, the as-cast coarse grains can be divided into several parts by slipping and shear bands for matching the deformation of the adjacent grains with different misorientations, and the grain boundaries could be waved due to grain-boundary slipping (Figure 3a). When the reduction increased up to the critical strain of DRX, dislocations piling up at the grain boundaries and the slipping bands could be evolved into regular configurations such as sub-grains, where DRX nuclei formed preferentially, as shown in Figure 3b and Figure 4. Then the DRX volume fraction increased with the increasing amount of reduction, as shown in Figures 3c and 3d. Although the newly formed DRX refined grains have a lower dislocation density, the strength of the deformation material can be improved by the refined DRX grains based on the Hall-Petch relationship at room temperature; and the plasticity of the deformation material can also be improved by the refined DRX grains, as shown in Table 3. Satio found that a high strain rate and a low final rolling temperature 

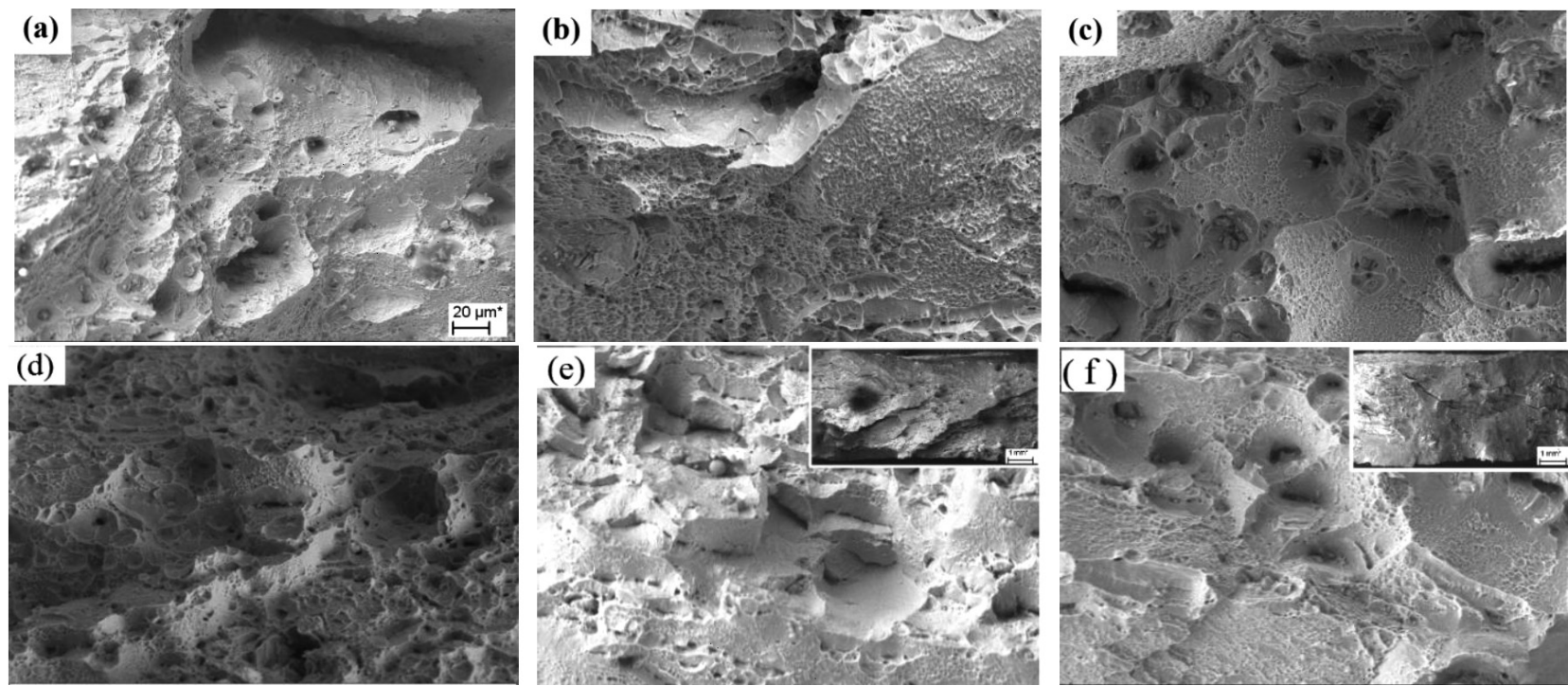

Figure 8: Fracture morphologies of the single-pass rolled parts with reductions of: a) $15 \%$, b) $30 \%$, c) $40 \%$, d) $50 \%$, and e) of the three-pass rolled part and $\mathrm{f}$ ) of the five-pass rolled part

provide time and energy that is not enough for merging and the growth of sub-grains, and DRX/SRX occurs slowly. ${ }^{18}$ Therefore, only a few DRX/SRX refined grains can be observed in Figure $\mathbf{6 a}$ and Figure $\mathbf{7 a}$, and the fractions of LAGB in Figure $\mathbf{6 b}$ and Figure $\mathbf{7 b}$ were much higher. However, a large number of slipping or shear bands can be observed in the elongated grains after the three-pass and five-pass rolling processes, especially after the five-pass rolling process due to the lower reduction of each pass. The slipping bands or shear bands with a higher energy can be seen as the preferential nucleation sites and accelerate the DRX during the rolling processes. ${ }^{19}$ Qin also found that a large number of deformation micro-bands were observed in the interior of the deformed columnar grains at higher strain rates. ${ }^{9}$ The interfaces between deformed micro-bands can serve as preferential nucleation sites for DRX. Chen ${ }^{10}$ found that the hot-processing windows for $\mathrm{ESR}$ Mn18Cr18 steel were $1050-1200{ }^{\circ} \mathrm{C}, 0.001-0.01 \mathrm{~s}^{-1}$ and 1100-1200 ${ }^{\circ} \mathrm{C}, 0.1-1 \mathrm{~s}^{-1}$. It indicated that a high individual pass reduction or a high final rolling temperature was necessary for refined recrystallized grains and improved properties. During a subsequent solid-solution treatment, DRX and SRX proceed continuously. Then the fully recrystallized grain structure can be obtained in
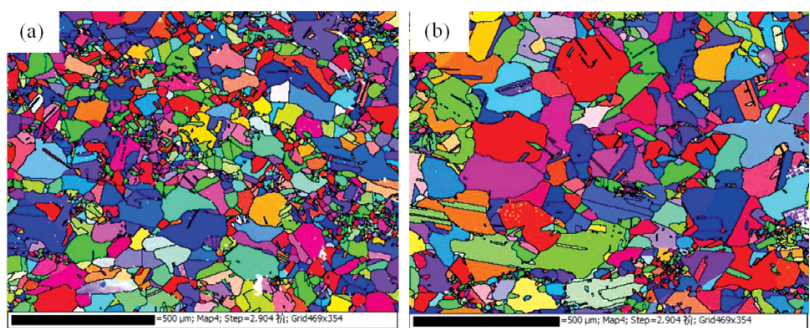

Figure 9: a) Solid-solution treated microstructures of the three-pass rolled and b) five-pass rolled samples
Figure 9a, because the solid-solution treatment temperature and time were appropriate $\left(1050{ }^{\circ} \mathrm{C} / 2 \mathrm{~h}\right)$. However, the fully static recrystallized grains will grow (Figure 9b) at higher temperatures after a prolonged period. After the solid-solution treatment, the uniform refined recrystallized grain structure can provide increased plasticity of the rolled parts. The average grain sizes in Figures 9a and 9b were about $83 \mu \mathrm{m}$ and $130 \mu \mathrm{m}$, respectively.

Table 3: Mechanical properties of the rolled parts

\begin{tabular}{|c|c|c|c|c|}
\hline $\begin{array}{c}\text { Rolling } \\
\text { pass }\end{array}$ & $\begin{array}{c}\text { Reduction } \\
c / \%\end{array}$ & $\begin{array}{c}\text { Yield } \\
\text { strength, } \\
R_{\mathrm{eL}} / \mathrm{MPa}\end{array}$ & $\begin{array}{c}\text { Tensile } \\
\text { strength, } \\
R_{\mathrm{m}} / \mathrm{MPa}\end{array}$ & $\begin{array}{c}\text { Elongation, } \\
A / \%\end{array}$ \\
\hline \multirow{3}{*}{1} & 15 & 694 & 882 & 40.7 \\
\cline { 2 - 5 } & 30 & 719 & 886 & 43.4 \\
\cline { 2 - 5 } & 40 & 724 & 920 & 50.2 \\
\hline 3 & 60 & 740 & 930 & 51.5 \\
\hline 5 & 60 & 1027 & 1086 & 41.0 \\
\hline
\end{tabular}

\section{CONCLUSIONS}

The influence of hot-rolling reductions and passes on the microstructure and mechanical properties of the ESR Mn18Cr18N steel was investigated by hot-rolling experiments. The microstructures and mechanical properties of the rolled parts were tested and analyzed by SEM, EBSD and tensile tests. The conclusions can be drawn as follows.

(1) For the single-pass rolled process, the volume fraction of refined dynamically recrystallized grains increased with the increasing of the reduction. The near fully DRX refined grains with a size of about $50 \mu \mathrm{m}$ were obtained and $\delta$ ferrite could hardly be observed for the reduction up to $50 \%$. Both the tensile strength and 
the elongation also increased with the increasing of reduction, and the fracture morphology transformed to ductile at higher reductions.

(2) For the three-pass rolling processes, strain-hardening structures containing a large number of slip/shear bands and fewer refined dynamically recrystallized grains were present. Compared to the single-pass rolled part, the tensile strength increased, and the elongation decreased. The fracture morphology was characterised by brittle fracture. After the solid-solution treatment, uniform refined static recrystallized grains with an average grain size of about $83 \mu \mathrm{m}$ were obtained in the three-pass rolled part.

(3) For the five-pass rolling process, strain-hardening structures containing a large number of slip/shear bands and fewer refined dynamic recrystallized grains were present. The tensile strength increased with the increasing number of passes, but the elongation decreased with the increasing number of passes. The fracture morphology was characterised by brittle fracture. After the solid-solution treatment, the grain growth following the static recrystallization occurred in the five-pass rolled part. The average grain size was about $130 \mu \mathrm{m}$.

\section{Acknowledgments}

This work was financially supported by the National Natural Science Foundation of China (no. 51575372). Sponsored by the Fund for Shanxi Key Subjects Construction (20170401), Science and Technology Research Plan (Industrial) Project of Shanxi Province, China (no. 201603D121006-2).

\section{Compliance with ethical standards}

Conflict of interest. The authors declare that they have no competing interests.

\section{REFERENCES}

${ }^{1}$ F. Qin, Y. Li, W. He et al., Effects of deformation microbands and twins on microstructure evolution of as-cast $\mathrm{Mn} 18 \mathrm{Cr} 18 \mathrm{~N}$ austenitic stainless steel, J. Mater. Res., (2017), 1-11, doi:10.1557/jmr.2017. 389

${ }^{2}$ H. Y. Ha, T. H. Lee, C. S. Oh et al., Effects of combined addition of carbon and nitrogen on pitting corrosion behavior of $\mathrm{Fe}-18 \mathrm{Cr}-10 \mathrm{Mn}$ alloys. Scripta Mater., 61 (2009), 121-124, doi:10.1016/ j.scriptamat. 2009.03.018

${ }^{3}$ S. J. Zheng, X. D. Hao, Y. C. Hong et al., Austenitic grain growth behavior during austenitization of high nitrogen stainless steel.T Mater. Heat Treat, 38 (2017), 180-186, doi:10.13289/j.issn.10096264.2017-0052

${ }^{4}$ C. Zhang, S. Ji, Y. Zhao et al., Dynamic recrystallization behavior of low-nickel high nitrogen austenitic stainless steel. Heat Treat Met, 42 (2017) 31-34.doi:10.13251/j.issn.0254-6051.2017.07.008
${ }^{5}$ A. N. Hongping, J. S. Liu, C. C. Yang et al., Research on the numerical simulation and the experimentation of the punching-extrusion process with an outer ring for $\mathrm{Mn} 18 \mathrm{Cr} 18 \mathrm{~N}$ retaining ring, Forging \& Stamping Technology, 31 (2006), 127-130, doi:10.3969/j.issn.10003940.2006.06. 036

${ }^{6}$ X. Chen, Z. Jiang, F. Liu et al., Effect of melt rate on surface quality and solidification structure of $\mathrm{Mn} 18 \mathrm{Cr} 18 \mathrm{~N}$ hollow ingot during electroslag remelting process, Steel Res. Int., 88 (2017), 2, doi:10.1002/srin.201600186

${ }^{7} \mathrm{H}$. E. Wen Wu, Microstructure evolution of multi-heats forging of $\mathrm{Mn} 18 \mathrm{Cr} 18 \mathrm{~N}$ retaining ring steel and numerical simulation, Int. J. Plasticity 17 (2010), 45-49, doi:10.3969/j.issn.1007-2012.2010. 02.009

${ }^{8}$ Y. Liu, Z. Zhang, G. Li et al., Effect of current on structure and macrosegregation in dual alloy ingot processed by electroslag remelting, Metals-Open Access Metallurgy Journal, 7 (2017), 185, doi:org/10.3390/met7060185

${ }^{9}$ F. Qin, H. Zhu, Z. Wang, X. Zhao, W. He et al., Dislocation and twinning mechanisms for dynamic recrystallization of as-cast Mn18Cr18N steel, Mat. Sci. Eng. R,684 (2017), 634-644, doi:10.1016/j.msea.2016.12.095

${ }^{10}$ C. Huiqin, Z. Wang, F. Qin et al., Hot deformation behavior and processing maps of As-cast Mn18Cr18N Steel., J Wuhan Univ. Techno, 32 (2017), 935-943, doi:10.1007/s11595-017-1693-8

${ }^{11} \mathrm{Z}$. Xi, C. Wang, X. Liu et al., Microstructure evolution and mechanical hardening of $18-18-0.5 \mathrm{~N}$ high-nitrogen austenitic stainless steel during cold rolling, J. Univ. Sci. Technol. B, 30 (2008), 875-879, doi:10.3321/j.issn:1001-053X.2008.08.008

${ }^{12} \mathrm{~S}$. G. Shuttleworth, Industrial research: its organisation in Great Britain and the possible application of similar methods in South Africa, South African Journal of Economics, 7 (2010), 184-197, doi:10.1111/j.1813-6982.1939.tb02202.x

${ }^{13}$ A. A. Rubinstein, Dislocational pile-up-grain boundary interaction at elevated temperature, Mech. Mater.,5 (1986) 145-160, doi:10.1016/0167-6636(86)90030-X

${ }^{14}$ M. Rout, R. Ranjan, S. K. Pal et al., EBSD study of microstructure evolution during axisymmetric hot compression of 304LN stainless steel, Mat. Sci. Eng. A, 711 (2018), 378-388, doi:10.1016/ j.msea.2017.11.059

${ }^{15}$ F. Guo, D. Zhang, X. Fan et al., Deformation behavior of AZ31 Mg alloys sheet during large strain hot rolling process: A study on microstructure and texture evolutions of an intermediate-rolled sheet, J. Alloy Compd., 663 (2016), 140-147, doi:10.1016/ j.jallcom.2015.12.063

${ }^{16}$ S. Mandal, P. V. Sivaprasad, S. Venugopal et al., Constitutive flow behaviour of austenitic stainless steels under hot deformation: artificial neural network modelling to understand, evaluate and predict, Model. Simul. Mater. Sc., 14 (2006), 1053, doi:10.1088/ 0965-0393/14/6/012

${ }^{17}$ H. Paul, J. H. Driver, C. Maurice et al., The role of shear banding on deformation texture in low stacking fault energy metals as characterized on model Ag crystals, Acta Mater., 55 (2007), 575-588, doi:10.1016/j.actamat.2006.08.051

${ }^{18}$ Y. Saito, H. Utsunomiya, N. Tsuji, and T. Sakai, Novel ultra-high straining process for bulk materials development of accumulative roll-bonding (ARB) process, Acta Mater., 47 (1999), 579-583, doi:10.1016/S1359-6454(98)00365-6

${ }^{19}$ J. S. Hayes, R. Kyte, and P. B. Prangnell, Effect of grain size on the tensile behavior of a submicron grained $\mathrm{Al}-3 \% \mathrm{Mg}$ alloy produced by severe deformation, Mater. Sci. Technol., 16 (2000), 1259-1263, doi:10.1179/026708300101507479 